\title{
WHAT IS RIGHT AND WRONG IN MARKETING THE PHARMACEUTICAL PRODUCTS
}

\author{
Dr.Kamath Madhusudhana \\ Former Associate Professor, Division of Ayurveda, Centre for Integrative Medicine and Research, \\ Manipal Academy of Higher Education, Manipal-576 104, Manipal-576 401
}

Article DOI: https://doi.org/10.36713/epra6578

\begin{abstract}
Pharmaceutical marketing is the ability to reach the right health care professionals with the right note and spell. According to the Cambridge English Dictionary the business activity that involves finding out what customers want, using that information to design products and services, and selling them effectively. But recent studies on pharmaceutical marketing is full of controversy like issues and concerns of ethical and unethical marketing.
\end{abstract}

\section{INTRODUCTION}

Marketing is an integral part of promoting the new and existing product in the community. Marketing is the study and management of exchange of relationship with consumers. According to American Association Marketing (AAM) is the activity, set of institutions, and processes for creating, communicating, delivering, and exchanging offerings that have value for customers, clients, partners, and society at large. While marketing research is the function that links the consumer, customer, and public to the marketer through information-information used to identify and define marketing opportunities and problems.

A study conducted by the Bristol-Myers company to predict medical advance reveals that during 1986 rate of Cancer cure was about $50 \%$ but it is around $65 \%$ during 2002. Streptokinase was the drug of choice in MI with the risk of thrombolysis. But now advancement in technology has increased the rate of survival. It has been found that we can produce the artificial genome and we can regenerate nerve cells by using genetic engineering ${ }^{1}$. But at the same time, the Oxfam report says that the pharma industry is not interested in delivering its services to the developing countries $^{2}$.

The amount spent on health care research has tripled since the last two decades (Data till 2010). Its large contribution from pharmaceutical industries, Health care research requires more funding also. Health is one among the basic need of a human being and transparency is required in the pharmaceutical industry and the promotion industry. As WHO clearly says the Promotional materials for pharmaceutical products should be accurate, fair and objective and presented in such a way as to confirm not only to legal requirements but also to high ethical standards. It is observed that, whether it is big or small need for Artificial Intelligence (AI) has been increasing in the recent times The AI allowed organizations to extract information from multiple platforms and applications to take better decisions which drive tangible returns on their investments.

At the same time, Cyert and March's Behavior theory of Firm says that a firm is a unit having multigoal, multi-decision, and multi-product. If we just look towards the amount requires to invent a new drug molecule, it takes around seven years and costs 


\section{SJIF Impact Factor 2021: 7.13| ISI I.F.Value:1.241| Journal DOI: 10.36713/epra2016 EPRA International Journal of Research and Development (IJRD) \\ Volume: 6 | Issue: 3 | March 2021}

approximately $\$ 282$ million which can be reduced to more than $50 \%$ by conducting the same research in developing countries like India ${ }^{3}$ and main countries of Africa continent. i.e. what Rudolph Virchow said, "Medicine is a social science and politics is nothing but medicine on a large scale".

It is quite a common assumption that the Government is paying for basic research and corporate sector to applied research ${ }^{4}$. This can be altered slightly by imposing taxes on peoples those from developed countries like the US, Japan Consumers enjoys more Surplus, which should be used for applied research. And at the same time corporate sector, one who enjoys more Producers Surplus must involve in conducting Research in basic sciences like genetics, biochemistry etc and also gives more stress to the education. For instance: Bill and Melinda Gates funding $\$ 100,000$ each for 78 innovative projects which may help Society in future and Venus Remedies working along with Punjab University to develop Typhoid Detection kit, as Typhoid claims nearly 6,00,000 deaths annually around the world.

Dr Prathap Reddy of APOLLO Health Care Group, India says "Innovation and superior patient experience are the two aspects of our business model". While Experts says, countries must prepare for selfsufficiency in their health care system. Developed countries as well as WHO, they are giving more importance to the providing health care to those who are unable to afford, Rather than paying for research, education, and control over drug prices those which are much higher than production costs, Dr Mansfield said. Therefore tracking cost information enables the management to take appropriate decision while allocating resources as planned and observe their trends periodically.

\section{DISCUSSION}

Recently Muhammad Jami Husain et al mentions about the availability, accessibility and high costs of pharmaceuticals is an ongoing challenge to the countries under poverty and developing one. According to the World Health Organization (WHO), 2018, the world pharmaceutical market cost projected around \$ 1.4 trillion per annum across the world and trend suggests it increases globally. The study conducted on "Theory of planned behaviour" suggests that the effect of Physicians communication with pharma sales representatives on their behaviour prescription ${ }^{7}$. Apart from this pharmaceutical markets provide a rich work of innovative research opportunities for marketing academics. The marketing must be cognitively, affectively, and behaviorally oriented. Efforts have been put on an additional focus on pharma academics for better output. This only gives a healthier result. The public-private partnership must be in equal contribution from the pharma sector, especially MNCs and Govt, this may bring a dramatic shift in pharmaceutical academics. Developing countries must have their framework so that they can deliver goods on time. In developing countries that both public and private partnerships must emerge and develop services for the development of science. Former US President Ronald Reagan once said "Each generation goes further than the generation presiding it because it stands on the shoulder of that generation you will have opportunities beyond anything we"ve ever known"

\section{CONCLUSION}

The need for business intelligence and artificial intelligence provides an opportunity for new and small businesses to run their business operations efficiently and helping companies to grow faster. There is no wrong if any corporate company conduct or sponsor a CME to advertise or to share their development in R \& $\mathrm{D}$ but it is left to the medical community to decide what is wrong and right and also to decide what is their role and contribution to the society, Why because Medical fraternity is not an immature and unaware about ethics of practice as they aware about Hippocrates oath says" I will prescribe regimens for the good of my patients according to my ability and my judgment and never do harm to anyone" before staring their practice. The Artificial Intelligence systems also offer tools which help to get predictive analysis to forecast potential results of a decision. This kind of analysis can be seen in the cases of capital budgeting which greatly influence the future of an organization. Predictive analysis also helps organizations in building personalized marketing tactics keeping because of a shift in the market demand as well as designing a competitive price and deals to retain the customers. Ultimately it left to the doctor's community to encourage moral practice and pharmaceutical companies must decide how to use Producers Surplus as a bribe or to share with the scientific community for Humanitarian cause.

\section{REFERENCES}

1. Rob Stepney, Back to the future: how good are
doctors at gazing in the crystal ball?
BMJ 2006;333:1311-1313
2. Adrian O'Dowd, Drug companies are ignoring
health crisis in poor countries, Oxfam says.,
BMJ 2007;335:1111
3razier, Nicole C.; Levine, Mitchell A.H. Drug-
Herb Interaction Among Commonly Used
Conventional Medicines: A Compendium for 


\section{EPRA International Journal of Research and Development (IJRD)}

Volume: 6 | Issue: 3 | March 2021

- Peer Reviewed Journal

Health Care Professionals, American $J$ The

May/June 2003 - Volume 10 - Issue 3 - pp 163-169.

4. Melissa Sweet, Doctors and drug companies are locked in "vicious circle" BMJ 2004;329:998

5. Deb C, Curfman G. Relentless Prescription Drug Price Increases. Jama. 2020; 3;323(9):826-8.

6. Husain MJ, Datta BK, Kostova D, Joseph KT, Asma S, Richter P, Jaffe MG, Kishore SP. Access to Cardiovascular Disease and Hypertension Medicines in Developing Countries: An Analysis of Essential Medicine Lists, Price, Availability, and Affordability. Journal of the American Heart Association. 2020; 5;9(9):e015302.

7. Faisal A, Ahmad MS, Thurasamy R, Ahmed $R$. Doctors' Interactions with Pharmaceutical Sales Representatives: Modelling Doctors Prescription Behaviour. Community Mental Health Journal. 2020;56(3):456-63. 